\title{
Digitization of Educational Technology Centres for Teaching Electrical and Electronics Technology in Colleges of Education in North Eastern Nigeria
}

\author{
Dauda Moses ${ }^{1^{*}}$ \\ Nasiru Bello Mohammed ${ }^{2}$ \\ Amos Danlami Agbu ${ }^{3}$ \\ Lumo Adams Gainaka ${ }^{4}$ \\ ${ }^{1}$ School of Technology and Science Education, \\ MAUTECH, P. M. B. 2076 Yola, Adamawa State, Nigeria \\ ${ }^{2}$ School of Education, F.C.E (Technical), \\ P. M. B. 60 Gombe, Gombe State, Nigeria \\ ${ }^{3}$ Electrical Engineering Department, \\ Taraba State Polytechnic Suntai, \\ P. M. B. 1030 Jalingo, Taraba State, Nigeria \\ ${ }^{4}$ Ministry of Education, \\ P. M. B. 0064, Bauchi, Bauchi State, Nigeria \\ Corresponding Author
}

Doi: 10.2478/ajis-2018-0071

\section{Abstract}

The purpose of this study was to assess the level of digitization of Educational Technology Centres for teaching electrical and electronics technology in Colleges of Education in North Eastern Nigeria in order to provide information that will help solve problems of incompetence of public school students in Information and Communication Technology (ICT). The study, guided by two research questions and two hypotheses was conducted in six Colleges of Education in North Eastern Nigeria using descriptive survey research design. The sample of the study was 50 comprising of 15 non-teaching Educational Technology Centres staff and 35 Electrical and Electronics Technology lecturers from five colleges of education in North Eastern Nigeria. Checklist containing 103 expected digital facilities based on National Commission for Colleges of Education (NCCE) minimum standard for Educational Technology Facilities in Colleges of Education in North Eastern Nigeria was used as instrument for data collection. Respondents were required to fill in observed facilities in the required column. Arithmetic percentage and Chi-square test of goodness-of-fit and were used determine the extent of digitization of the Educational Technology Centres in Colleges of Education in North Eastern Nigeria. Findings of the study revealed among others that analog technologies has higher number of frequency counts compared to digital technologies, hence there was low digitization of hardware facilities in Educational Technology Centres in Colleges of Education in North Eastern Nigeria. The study therefore concluded that Educational Technology Centres in Colleges of Education in North Eastern Nigeria were not digitized for instructional purposes; therefore, Government should digitize Educational Technology Centres in Colleges of Education in North Eastern Nigeria by adequately providing both digital hard and soft ware facilities.

Keywords: Digitization, Educational Technology, Centres, Teaching, Colleges of Education

\section{Introduction}

Education is dynamic and tends to follow the pattern of development in the world and industrial revolution taking place in the global arena. To be relevant in a in speedily changing society in which 
technology transform every sector, learners are expected to; beside having mastery in art of communication, maths technology and sciences, it is imperative to have skills and competencies in areas such as critical thinking, problem-solving, persistence, and collaboration. However, learners in many countries are not attaining these skills. The World Economic Forum has observed a multiyear initiative, "New Vision for Education", to evaluate the pressing issue of skills and competency gaps and explore ways to address such gaps through provision of recent digital educational facilities for teaching (World Economic Forum, 2015).

The call for the application of digital technologies learning facilities in instructional delivery in COEs is a means of infusing and injecting efficiency and effectiveness in curriculum implementation in technical education. However, in developing countries like Nigeria, the use of digital technologies in instructional delivery is challenged with problems ranging from lack of trained personnel, digital technologies learning materials such as computers, on-line internet computers, telephones, wireless scanners, printers, e-mail facilities, multimedia television, multimedia projectors, digital Libraries, computer assisted instructions (CAIs) among others (Global Information Technology Report, 2005 in Atueyi \& Ikemelum, 2014).

Colleges of Education have not discharged their duties well in equipping present day youths with relevant teaching skills necessary for effective instructional delivery in the $21^{\text {st }}$ Century (Ololube, Ubogu \& Egbezor, 2006). The inability to integrate recent digital technologies in instructional delivery in may put the Colleges of Education at a global competitive disadvantage as the colleges would probably be producing low quality teachers at higher cost. The danger here is that if analog and absolute facilities remain in instructional delivery in the Colleges of Education, the objectives of Technical Education in Nigeria may became an illusion and may have a ripple effect on higher education. This situation will eventually bring the Colleges of Education to a halt and eventually pose serious limitations to students' learning (Ibidapo-Obe, 2007).

The development and impact of digital technologies necessitated educational technology centres in Colleges of Education in North Eastern Nigeria to migrate from analog to digital technologies for the sole purpose of equipping teachers with relevant skills (such as digital technologies and information technology literacy; problem-solving skills and the ability to use digital technology in evaluating and utilizing information and communication technologies for problemsolving in addition to knowledge of subject's contents) as stipulated in the National Policy on Education (FRN,2013). These knowledge components often considered as ICT-literacy has become part of basic labour requirements in knowledge driven societies and a necessary foundation for higher and lower levels of education and professional development.

Information and Communication Technology (ICT) has produced changes in the economic, political and educational sphere of our daily lives, such that it has become an important index of national and economic development and basic building block of modern society. Globally, the ICT world has initiated a transition of emphasis from analog educational research based technological development to that of digital knowledge based technological development in education (Jude \& Dankoro, 2012). Digital technologies for teaching and learning became the strategic alternatives for the Colleges of Education to enhance effective and efficient delivery of quality education.

Among the issues that permeate the educational literature in $21^{\text {st }}$ century include: the need to provide youths with necessary tool to succeed by providing them with a means to understand how to gain cognizance with the subject matter effectively and develop problem solving skills which are significant and adaptive, to produce students who are creative, communicative and inventive as well as been culturally compassionate and conscious in all situations and conduct themselves in a socially responsible way, and the demand for developing in the learners, digital literacy in order to keep in phase with recent technological developments which present numerous promises and also needs the opinion to make sure the influence of technology is utilized reliably in what Gardner (2012) called " good work". Educational resources are crucial in curriculum development and implementation in Nigerian technical colleges. This is evident in the movement of developing countries to develop STEM curriculum to train learners for the challenges of the information age. Some have proposed that (STEM) acronym should be expanded to that of Science, Technology, Engineering, Arts, Language, and Mathematics (STEAM) if educators truly wish to embrace creativity and innovation in all its forms (Catchan, 2013). In contemporary society Colleges of 
Educations have transformed to encompass dual modes where both online and on-campus learning options are available (Power, 2008). New digital facilities allow more flexible and innovative educational technology and course design solutions (Olofsson \& Lindberg, 2012; Schneckenberg, 2009). This is also the case in Education, where the use of digital facilities to enhance students' learning has grown rapidly (Maley, Harvey, De Boer, Scott, \& Arena, 2008).

In order to cope effectively with challenge of equipping teachers with knowledge that bears relevance to the present need of $21^{\text {st }}$ century of digital ICT age, ETCs that contain analog facilities in Colleges of Education in North Eastern Nigeria need to migrate from analog technologies to digital technologies at all levels. Such migration need to reflect on meaningful changes in infrastructure, educational technology facilities, curriculum and pedagogical practices (Emmanuel, Chiaka, \& Edna, 2014). This transformational in the mode of imparting knowledge to students is the prime concern of educational business ((Ololube, Ubogu \& Egbezor, 2006). The compelling need therefore to know the level of digitization of educational technology centres to accommodate the wide range of digital literacy shift in for teaching electrical and electronics technology in Colleges of Education in North Eastern Nigeria cannot be overemphasized.

\subsection{Purpose of the Study}

The purpose of this study was to investigate the level of digitization of Educational Technology Centres for teaching Electrical and Electronics Technology in Colleges of Education in North Eastern Nigeria and specifically to determine the:

1. Extent of digitization of hardware in Educational Technology Centres for Teaching Electrical and Electronics Technology in Colleges of Education in North Eastern Nigeria?

2. Extent of digitization of software in Educational Technology Centres for Teaching Electrical and Electronics Technology in Colleges of Education in North Eastern Nigeria?

\subsection{Research Questions}

To achieve the above stated specific purposes, the following research questions were used to guide the study:

1. To what extent are hardware digitized in Educational Technology Centres for Teaching Electrical and Electronics Technology in Colleges of Education in North Eastern Nigeria?

2. To what extent are software digitized in Educational Technology Centres for Teaching Electrical and Electronics Technology in Colleges of Education in North Eastern Nigeria?

\subsection{Research Hypotheses}

Two hypotheses guided the study as follows:

$\mathrm{HO}_{1}$ : There is no significant difference between the number of digital and analog hardware in Educational Technology Centres for teaching electrical and electronics technology in Colleges of Education in North Eastern Nigeria.

$\mathrm{HO}_{2}$ : There is no significant difference between the number of digital and analog software in Educational Technology Centres for teaching electrical and electronics technology in Colleges of Education in North Eastern Nigeria.

\section{Methodology}

The study which employed a descriptive survey design was carried out in North Eastern Nigeria which lies between Latitude $6^{0} 18^{1}$ to $14^{0} 32^{1} \mathrm{~N}$ and Longitude $10^{0} 11^{1}$ to $14^{0} 35^{1} \mathrm{E}$ (Mohammed, 1999). The area of the study was chosen because there are adequate colleges of education where electrical and electronics technology education is taught. The population of the study was 50 , comprising of 15 non-teaching educational technology centres staff and 35 electrical and electronics technology lecturers from five colleges of education in North Eastern Nigeria. The whole population was used for the study hence, there was no sampling. 
The instrument used for data collection was a checklist containing 103 expected facilities based on National Commission for Colleges of Education (NCCE) minimum standard for educational technology facilities in Colleges of Education in North Eastern Nigeria. Respondents were required to fill in observed facilities in the required column against the column for expected facilities.

Data collected for the study was analyzed the arithmetic percentage and chi-square test of goodness-of-fit. The arithmetic percentage was used to answer the two research questions while the chi-square test of goodness-of-fit was used to test the two null hypotheses at 0.05 level of significance. All the data analyses were conducted using Statistical Package for Social Sciences (SPSS) version 20.0 for windows. The decision on the extent of digitization of facilities for teaching electrical and electronics technology in educational technology centres based computed percentages of observed facilities was as follows: 76-100\%; Very High Extent, 51-75\%; High Extent, 26-50\%; Low Extent and 00-25\%; Poor Extent.

\section{Results}

Results of the study were presented as follows:

\subsection{Research Question 1}

To what extent are hardware digitized in Educational Technology Centres for Teaching Electrical and Electronics Technology in Colleges of Education in North Eastern Nigeria?

Table 1. Extent of Digitization of Electrical and Electronics Hardware Facilities in Educational Technology Centres

\begin{tabular}{clcccc}
\hline S/N & Items & No. Observed & No. Expected & Percentage Observed & Remarks \\
\hline 1 & CCTV (Closed Circuit Television) & 5 & 12 & 42 & LE \\
2 & VCD (Video Compact Disc) player & 15 & 2242 & 0.7 & LE \\
3 & CD-RW (Rewritable Media) & 12 & 2242 & 0.5 & LE \\
4 & On-Line Computers & 1 & 2073 & 0 & LE \\
5 & Opaque Projectors with accessories & 30 & 468 & 6 & LE \\
6 & Slide Projector with Accessories & 42 & 468 & 9 & LE \\
7 & Over Head Projector with Accessories & 44 & 429 & 10 & LE \\
8 & Duplicating Machine & 17 & 46 & 37 & LE \\
9 & Photocopiers & 40 & 66 & 61 & HE \\
10 & Video Home System (VHS) & 28 & 225 & 12 & LE \\
11 & 16 mm Film Projectors & 32 & 81 & 40 & LE \\
12 & 35mm Film Projectors & 40 & 56 & 71 & HE \\
13 & Film Strips Projectors & 32 & 441 & 7 & LE \\
14 & Off-Line Computers & 18 & 282 & 6 & LE \\
15 & Scanners & 4 & 60 & 7 & LE \\
16 & Printers & 4 & 78 & 5 & LE \\
17 & Multi-Media Television & 17 & 233 & 7 & LE \\
18 & Multi-Media Projector & 21 & 124 & 17 & LE \\
19 & Digital Photographic Equipment & 3 & 264 & 1 & LE \\
20 & Motion Pictures Layer 3 (MP 3) & 4 & 2244 & 0 & LE \\
21 & Motion Pictures Layer 4 (MP 4) & 0 & 2038 & 0 & LE \\
22 & Interactive Boards & 4 & 274 & 2 & LE \\
23 & Still Cameras & 16 & 2076 & 1 & LE \\
24 & Video Cameras & 18 & 654 & 3 & LE \\
25 & Converters & 0 & 055 & LE \\
26 & Optical Readers & 0 & 445 & 0 & LE \\
27 & Multi-Media digital Storage & 3 & 2244 & 0 & LE \\
28 & i-pads & 1 & 2244 & 0 & LE \\
\hline Key HE = Hign Extent LE Low Extent & & & &
\end{tabular}

Key: HE = High Extent, LE $=$ Low Extent 
Table 1 indicated low digitization in 26 items while two items which includes item 9; photocopiers and item 12; 35mm film projectors which are analog facilities had high percentages, indicating that 26 out of 28 hardware for teaching Electrical and Electronics Technology in Educational Technology Centres in Colleges of Education in North Eastern Nigeria are not digitized.

\subsection{Research Question 2}

To what extent are software digitized in Educational Technology Centres for Teaching Electrical and Electronics Technology in Colleges of Education in North Eastern Nigeria?

Table 2. Extent of Digitization of Electrical and Electronics Software in Educational Technology Centres

\begin{tabular}{|c|c|c|c|c|c|}
\hline $\mathrm{S} / \mathrm{No}$ & Items & No. Observed & No. Expected & Percentage Observed & Remarks \\
\hline 29 & Multi-Sim & 0 & 82 & 0 & LE \\
\hline 30 & Electronics Work Bench & 0 & 82 & 0 & LE \\
\hline 31 & Web 2.0 & 0 & 82 & 0 & LE \\
\hline 32 & Wikis & 0 & 82 & 0 & LE \\
\hline 33 & Podcast & 0 & 82 & 0 & LE \\
\hline 34 & Blogs & 2 & 82 & 2 & LE \\
\hline 35 & Stencils & 38 & 82 & 46 & LE \\
\hline 36 & Audio Tapes & 143 & 82 & 174 & $\mathrm{HE}$ \\
\hline 37 & Video Tapes & 272 & 82 & 331 & HE \\
\hline 38 & Slides & 479 & 82 & 584 & $\mathrm{HE}$ \\
\hline 39 & $16 \mathrm{~mm}$ Films & 49 & 82 & 60 & $\mathrm{HE}$ \\
\hline 40 & $35 \mathrm{~mm}$ Films & 14 & 82 & 17 & LE \\
\hline 41 & Video Cassettes & 261 & 82 & 318 & $\mathrm{HE}$ \\
\hline 42 & Tempo Markers & 37 & 82 & 45 & LE \\
\hline 43 & Poster Colors & 22 & 82 & 27 & LE \\
\hline 44 & Over Head Transparencies & 73 & 82 & 89 & LE \\
\hline 45 & Transparency Pens & 93 & 82 & 113 & $\mathrm{HE}$ \\
\hline 46 & Micro Soft Power Point & 6 & 82 & 7 & LE \\
\hline 47 & Micro Soft Excel & 3 & 82 & 4 & LE \\
\hline 48 & Magnifier & 3 & 82 & 4 & LE \\
\hline 49 & Micro Soft Out Look & 4 & 82 & 5 & LE \\
\hline 50 & E-microscopes & 4 & 82 & 5 & LE \\
\hline 51 & Micro Soft Picture & 4 & 82 & 5 & LE \\
\hline 52 & Smart Board & 4 & 82 & 5 & LE \\
\hline 53 & Online Images & 2 & 82 & 2 & LE \\
\hline 54 & Online Posters & 0 & 82 & 0 & LE \\
\hline 55 & Online Graphics & 2 & 82 & 2 & LE \\
\hline 56 & Clip Arts Images & 1 & 82 & 1 & LE \\
\hline 57 & Internet Protocol Camera & 0 & 82 & 0 & LE \\
\hline 58 & Online Maps & 0 & 82 & 0 & LE \\
\hline 59 & Graphics software & 5 & 82 & 6 & LE \\
\hline 60 & Web Cams & 0 & 82 & 0 & LE \\
\hline 61 & Dictionary & 5 & 82 & 6 & LE \\
\hline 62 & Computer Assisted Instruction Packages & 3 & 82 & 4 & LE \\
\hline 63 & E-Mail Facilities & 0 & 82 & 0 & LE \\
\hline
\end{tabular}

Key: HE = High Extent, LE = Low Extent

Table 2 indicated low digitization of 29 items while six analog items had high extent of digitization, indicating that 29 out of 35 software items for teaching Electrical Electronics Technology in the Educational Technology Centres and are low digitized. This indicated that digitization of software is yet to be embraced in Educational Technology Centres for teaching Electrical and Electronics Technology in Colleges of Education in Northeastern Nigeria. 


\subsection{Hypothesis 1}

There is no significant difference between the number of digital and analog hardware in Educational Technology Centres for teaching electrical and electronics technology in Colleges of Education in North Eastern Nigeria.

Table 3. Chi-Square Test of Difference in the Number of Hardware in Educational Technology Centres

\begin{tabular}{lccccc}
\hline S/N Technology & Total & $x^{2}$ cal. & $\chi^{2}$ crit. & Df & Decision \\
\hline 1 Digital & 23 & 23315.3 & 40.113 & 26 & Rejected \\
2 Analog & 5 & 26.3 & & \\
\hline
\end{tabular}

In table 3 above, Chi-square statistics result showed that $x^{2}$ cal. $=23315.3$ was greater than $x_{\text {crit. }}^{2}=$ 40.113 hence the null hypothesis was rejected indicating a significant difference in the number of digital and analog electrical and electronics hardware in Educational Technology Centres in Colleges of Education in North Eastern Nigeria.

\subsection{Hypothesis 2}

There is no significant difference between the number of digital and analog software in Educational Technology Centres for teaching electrical and electronics technology in Colleges of Education in North Eastern Nigeria.

Table 4. Chi-Square Test of Difference in the Number of Software in Educational Technology Centres

\begin{tabular}{lccccc}
\hline S/N Technology & Total & $X^{2}$ Cal. & $X^{2}$ Crit. & Df & Decision \\
\hline 1 Digital & 24 & 4772.1 & 46.194 & 33 & Rejected \\
\hline
\end{tabular}

Table 4 showed Chi-square statistics result with $x_{\text {cal }}^{2}=4772.1$ which is greater than $x^{2}$ crit. $=46.194$ hence the null hypothesis was rejected indicating that there was significance difference in the number of the digital and analog electrical and electronics software in Educational Technology Centres in Colleges of Education in North Eastern Nigeria

\subsection{Findings of the Study}

Based on the data analyzed with respect to the two research questions and two null hypotheses that guided the study, the following findings emerged.

1. There is low digitization of hardware facilities for teaching electrical and electronics technology in educational technology centres in Colleges of Education in North Eastern Nigeria.

2. There is low digitization of software facilities for teaching electrical and electronics technology in educational technology centres in Colleges of Education in North Eastern Nigeria

3. There was significant difference between the expected digital and analog hardware for teaching electrical and electronics technology in educational technology centres in Colleges of Education in North Eastern Nigeria

4. There was significant difference between the expected digital and analog software for teaching electrical and electronics technology in educational technology centres in Colleges of Education in North Eastern Nigeria 


\subsection{Discussion}

Findings of the study regarding research question 1 revealed low extent of digitization of hardware facilities for teaching electrical and electronics technology in Educational Technology Centres in Colleges of Education in North Eastern Nigeria. The finding showed that both analog and digital hardware facilities are low digitized in the Educational Technology Centres. Longe, (2013) argue in support of the findings of the study, public and private colleges have inadequate analog/digital facilities for teaching in ETCs. In response to the condition of Educational Technology Centre for effective teachers education in Nigeria, Udo (2006), agreed that availability, relevance and adequacy of hardware contribute to perceived students' learning outcome. The findings of this study however, disagreed with the findings of Oyeronke, Ogunlade, and Amos (2013), that facilities and equipment in educational technology centres in some selected Universities in Nigeria were averagely adequate. The difference in these findings was seen to be largely due to the fact that the study conducted by Oyeronke, Ogunlade, and Amos (2013), was conducted in the Universities where the National Universities Commission (NUC) placed more emphasis on educational technology.

Findings on research question 2 revealed low extent of digitization of software facilities for teaching electrical and electronics technology in Educational Technology Centres in Colleges of Education in North Eastern Nigeria. It was found out that a wide difference exists between the analog and digital software expected in Educational Technology Centres in Colleges of Education in North Eastern Nigeria. Both analog and digital software are not adequate in the Educational Technology Centres, an indication that the process of digitization of software in the Educational Technology Centres is slow. This finding was in agreement with findings of Tella (2011), who in his study found that software such as compact disks (CDs) and other digital and analog software were not available, let alone, being used for instructional purpose in colleges of education in South Western Nigeria. The findings also agreed with the findings of Wodi (2009), on the concept of educational technology and the problems prospects of Information and Communication Technology (ICT) in Nigeria. Wodi (2009) found out that soft wares produced overseas are grossly unavailable for teaching and learning in the nations' undergraduate programmes.

Findings of the study on hypotheses 1 and 2 revealed that a significant difference existed between the expected digital and analog electrical and electronics hard and soft wares in educational technology centres in for teaching electrical and electronics technology Colleges of Education in North Eastern Nigeria. The inadequacies of most of the facilities are absoluteness and non-functionality. In line with these findings was that of Oshinaike and Adekunmisi, (2012), whose findings indicated that multimedia hard and soft wares in Nigerian University System are grossly inadequate.

\section{Conclusion}

Based on the results of this study, it can be concluded that both hard and soft ware facilities in educational technology centres for teaching electrical and electronics technology in Colleges of Education in in North Eastern Nigeria are not digitized hence cannot be connected with the computer for classroom instruction. Both hard and software facilities in the educational technology centres are not adequate when compared to the number of students that utilize the facilities. The study also concludedthat significant difference existed between the expected digital and analog hard and soft wares in educational technology centres for teaching electrical and electronics technology in Colleges of Education in North Eastern Nigeria.

\section{Recommendations}

Based on the conclusions, the following recommendations were drowned to the issues addressed by the research questions and hypotheses of this study:

1. Government should digitize the educational technology centres in Colleges of Education in North Eastern Nigeria by adequately providing both digital hard and soft wares facilities 
2. More digital hard and soft ware facilities should be procured in educational technology centres for teaching electrical and electronics technology in Colleges of Education in North Eastern Nigeria

\section{Sources of Funding of the Study}

All costs, including that of undertaking the research study, transportation and welfare of both researchers and assistants were financed by the authors.

\section{Acknowledgements}

The researchers acknowledged the contributions of the following to the success of the study: Prof. V. V. Apagu, Prof. L. C. Ezugu, Prof. K. R. E. Okoye, Prof. D. K. Diraso, Prof. E. V. Mbaga and Dr. J. D. Medugu. The cooperation of all staff of educational technology centres including those in the micro teaching laboratories and electrical and electronics technology lecturers in colleges of education in north eastern Nigeria is also acknowledged.

\section{Reference}

Atueyi, B. J. \& Ikemelum, F. K. L.(2014). Multimedia of school. Nijmegen: Institute voor Toegepaste Sociale wetenschappen, Ubbergen: Tandem Felix. Spotts, T.H. (1999). Discriminating factors in faculty use of instructional technology in higher education.Journal of Educational Technology and Society, 2(4),95.

Catchan, R. (2013). Reflections: How STEM becomes STEAM. The STEAM Journal, 1(1),22

Emmanuel, C. N., Chiaka, A. O. \& Edna, N. (2014) Integration of Information Communication Technology (ICT) in the Curriculum of Federal Unity Schools in Nigeria: Implications for Learning. Greener Journal of Educational Research vol.4 (4) P p: 91-98. [Online] Available:http://dx.doi.org/10.15580/GJER.2014.4.021714113(May 5, 2016)

Federal Republic of Nigeria (FRN), (2013).National Policy on Education (Rev.ed.).Lagos:NR

Gardner, H. (2012). Commentary, getting at the heart of the creative experience.Creativity: Insights, directions, and possibilities. Learning Landscapes, 6(1), 45-48

Ibidapo-Obe, O. (2007) The Challenges of teacher education in Nigeria: The University of Lagos Experience. Paper presented at the Second Regional Seminar for Africa, UNESCO Forum on Higher Education, Research and Knowledge, Accra, 36(4), 21-22.

Jude W. I. \& Dankaro J. T. (2012).Resources utilization, availability and accessibility by teacher educators for instructional development in colleges of education, Kastina-Ala. New Media and Mars Communication.3 (3), 1-6

Longe, A. G. (2013), An Impact Assessment Study on the Role of Educational Technology in the Provision of Skills and Competencies in the Design of Instructional Materials in Higher Education Institutions in Lagos State Nigeria. Computing, Information Systems \& Development Informatics.3 (4), 34-45

Maley, M. A. L., Harvey, J. R., De Boer, W. B., Scott, N. W., \& Arena, G. E. (2008). Addressing current problems in teaching pathology to medical students: Blended learning.Medical Teacher, 30(3),1-9.

Olofsson, A. D. \& Lindberg, J. O. (Eds.) (2012).Informed design of educational technologies in higher education. Hershey. IGI Global.

Ololube, N. P., Ubogu, A. E., \& Egbezor, D. E. (2006). ICT and Distance Education Program in a Sub-Saharan African Country: A Theoretical Perspective. Journal of Information Technology Impact, 7(3),181-194.

Oshinaike, A. B. \& Adekunmisi, S. R. (2012). "Use of Multimedia for Teaching in Nigeria University System: A Case Study of University of Ibadan" Library Philosophy and Practice (e journal). Paper 682. [Online] Available: http://digitalcommons.unl.edu/libphilprac/682 (May 7, 2016)

Oyeronke, O. O. \& Amos, A. O. (2013).Evaluation of the adequacy, suitability and use of educational technology in selected faculties of education in Nigeria. Academic Journals http://www.academicjournals.org/JMCS Journal of Media and Communication Studies,4(4),38-43.

Power, M. (2008). A dual-mode university instructional design model for academic development. International Journal for Academic Development, 13(1),5-16.

Schneckenberg, D. (2009). Understanding the real barriers to technology-enhanced innovation in higher education.Journal of Educational Research, 51(4),411-424.

Tella, A. (2011).Availability and use of ict in south-western Nigeria colleges of education. Ethiopia International Multidisciplinary Journal, 5(5),315-331.

Udo, E. U.(2006). Availability, selection and utilization of instructional resources for teaching primary science in 
uyo local education authority, Akwalbom State.Resources for Science Technology and Mathematics (STM) Education. Science Teachers Association of Nigeria Proceedings of the $47^{\text {th }}$ Annual Conference

Wodi, S. H., (2009). New technologies for teaching and learning: Challenges for higher learning institutions in developing countries. International Journal of Education and Development using ICT, 3(2), 56.

World Economic Forum, (2015). New Vision for Education: Unlocking the Potential of Technology. [Online] Available: www.weforum.org (April 21, 2016) 